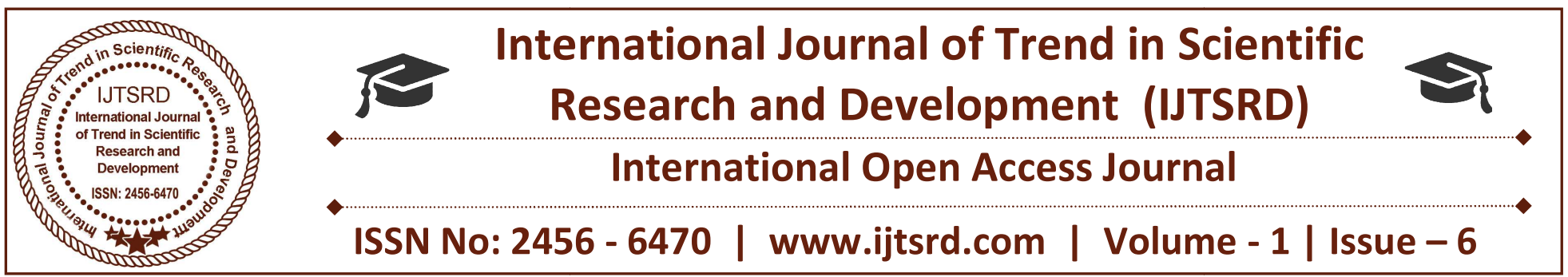

\title{
How Managers use Accounting to Make Better Decisions
}

\author{
K. M. Srisruthi \\ BBA. LLB.(Hons.), Saveetha School of Law, \\ Chennai, Tamil Nadu
}

\begin{abstract}
Addressing the topics of decision-making and also the use of knowledge covers a good vary of fields, every with its own perspective. My paper focuses on the role of monetary accounting informations in social control decision-making. The findings of my paper unconcealed that money accounting informations facilitate managers recognise what happened within the past and that is that the gift state of affairs of the corporate, create visible those events that don't seem to be perceptible by daily activities, give a quantitative summary of the corporate and facilitate managers for future activities and choices. To be useful for deciding, money accounting data should be intangible, relevant, reliable and comparable. The fact of decision-making reveals that choices square measure taken not solely in terms of informations and standing quo, however supported personal beliefs and representations that form the non-public vision of the planet.
\end{abstract}

\section{INTRODUCTION}

Accounting provides management with knowledge required to work out whether or not a business is at a loss or a profit, what quantity debtors owe, what quantity a business owes others, and different monetary data. Accounting measures business transactions and in and of itself will facilitate steer managers within the right direction with solid data, not gut-feelings. Essentially accounting could be a tool for management to use to assist build sound business choices on a timely manner. For example, if by victimisation accounting data, manager's notice that the trend is for sales to decrease, then they'll take measures to prevent this trend. Perhaps they have to alter costs or decrease expenses to handle the downtrend. The key's that accounting gave them the clue that one thing might not be going consistent with arrange, enjoying a very important role in business management.

\section{ISSUES}

Management accounting techniques -- accounting procedures that emphasize current info and analysis for social control decision-making -- will give smallbusiness house owners with helpful info for creating business choices. However, this info is not while not fault or value. Ensuring you perceive a number of the issues associated with social control accounting info will assist you make sure that you simply implement social control accounting systems which will give a internet positive profit to your tiny business.

GAAP Compliance: One of the largest complaints regarding management accounting techniques is that a lot of those techniques don't seem to be compliant with usually accepted accounting principles, or GAAP. As an example, activity-based cost accounting will give additional correct cost accounting info to decision-makers through an alternate approach of distribution prices to merchandise. For smallbusiness house owners, this will become expensive. If this is often not the case, then it in all probability is not well worth the time and cash. 


\section{Adaptability:}

While some pointers exist for management accounting procedures, the techniques

area unit ready to be tailored to the specifics of your business. This will be a plus of management accounting, however is additionally a downside. as a result of management accounting is thus versatile, it are often troublesome to check results across corporations, particularly if you're inconsistent in applying management accounting techniques inhouse. However, what one manager finds necessary is Also totally different than what another manager finds necessary. If the ways accustomed manufacture the comparisons don't seem to be identical, then faulty conclusions area unit doubtless.

\section{Reliability:}

Management accounting techniques sometimes emphasize the timeliness of knowledge to permit business house owners to form choices. this suggests a trade-off with dependability. However, if you would like this info for a call that you simply area unit designing on creating within the gift, then timeliness of knowledge is additional necessary.

\section{Cost:}

Management accounting info are often expensive. In several cases, management accounting techniques need time and cash to style, implement, monitor and value. This will involve moving current workers aloof from their traditional job duties, hiring further workers or hiring external consultants. The technique prepares totally different value estimates supported uncertainty in prediction.

\section{CONCLUSION:}

Managers will use social control statements to see if a product isn't moving as quick because it ought to. primarily based upon the data found on the statements the manager will make decisions place to the item on Associate in Nursing finish cap for show or they'll put the item on sale to come up with interest from and facilitate to spice up the revenue for the things that don't seem to be moving at an honest pace for the corporate. All of which may create a distinction if the numbers on the statements don't seem to be wanting nearly as good as they ought to. Investors and creditors UN agency have an interest in an exceedingly company will use money statements to try and do aspect by aspect comparisons on however one company stacks up against another in similar fields of business. All of which may facilitate create or break the company's ability to grow and sustain future business.

\section{REFERENCE:}

1) Professional Accountants in Business Committee (2009). Evaluating and rising cost accounting in Organizations (International smart observe Guidance). International Federation of Accountants. p. 7. ISBN 9781608150373

2) (Burns, Quinn, Warren \&amp; Oliveira, Management Accounting, McGraw-Hill, London, 2013)

3) "Definition of Management Accounting" (PDF). Institute of Management Accountants. 2008. Retrieved four Dec 2012.

4) http://www.cgma.org/Resources/Reports/Pages/ -GlobalManagementAccountingPrinciples.aspx

5) King, I. "New set of accounting principles will facilitate drive property success".

ft.com. Retrieved twenty eight Jan 2015.

6) van der Merwe, Anton (7 Sep 2011). Presentation at IMA's annual conference - social control cost accounting abstract Framework Session. Orlando, FL: unpublished. 